\title{
Modernisering van de personenvennootschappen
}

\author{
Column
}

Mr. E.A. van Dooren*

\begin{abstract}
Onlangs heeft de minister van Veiligheid en Justitie een rapport over de modernisering van de personenvennootschappen in ontvangst genomen. Het rapport is opgesteld door de Werkgroep Personenvennootschap en bevat een voorgestelde regeling met aanbevelingen voor het oplossen van bekende knelpunten en de opvulling van lacunes onder het huidige recht.
\end{abstract}

Op 26 september 2016 heeft de Werkgroep Personenvennootschap haar rapport over de modernisering van de personenvennootschappen aangeboden aan minister Van der Steur. De werkgroep betreft een particulier initiatief van juristen en fiscalisten uit de praktijk, de wetenschap en het bedrijfsleven, onder leiding van prof. Martin van Olffen. ${ }^{1} \mathrm{Zij}$ is begin 2012 opgezet als een reactie op de intrekking van Ontwerptitel 7.13 van het Burgerlijk Wetboek (BW) (Kamerstuk 28746) en de Invoeringswet titel 7.13 BW (Kamerstuk 31065).

De huidige wettelijke regeling voor personenvennootschappen dateert van 1838 en is verspreid over verschillende wetten. Sindsdien hebben er geen noemenswaardige wetswijzigingen plaatsgevonden op dit gebied. Voor veel vraagstukken over de personenvennootschap is men daarom noodgedwongen aangewezen op jurisprudentie en literatuur. Als gevolg hiervan is deze rechtsfiguur sterk verouderd en moeilijk toegankelijk. Dat dit tot langdurige en kostbare procedures kan leiden, werd in 2015 pijnlijk duidelijk met drie arresten van de Hoge Raad. Deze zagen op elementaire onderwerpen zoals het afgescheiden vermogen van een VOF en haar vennoten in faillissement, ${ }^{2}$ aansprakelijkheid van een toetredende vennoot ${ }^{3}$ en de sanctie bij overtreding van het beheersverbod. ${ }^{4}$

\footnotetext{
* Mr. E.A. van Dooren is promovendus bij het Van der Heijden Instituut (OO\&R, Radboud Universiteit). Hij is als secretaris verbonden aan de Werkgroep Personenvennootschap.

1. Prof. mr. M. van Olffen (voorzitter), mr. J.M. Blanco Fernández, mw. mr S. Drion, prof. dr. P.H.J. Essers, mr. W.J.M. Gitmans, mr. V.A.E.M. Meijers, prof. mr. M.J.G.C. Raaijmakers, mr. A.J.S.M. Tervoort, prof. mr. W.J.M. van Veen, prof. mr. D.F.M.M. Zaman, mr. E.A. van Dooren (secretaris) en mr. T. Salemink (secretaris).

2. HR 6 februari 2015, ECLI:NL:HR:2015:251 (VDV Totaalbouw)

3. HR 13 maart 2015, ECLI:NL:HR:2015:588 (Carlande).

4. HR 29 mei 2015, ECLI:NL:HR:2015:1413 (Lunchroom De Katterug).
}

Het doel van de werkgroep is om een aanzet te geven tot een nieuwe regeling voor de personenvennootschap. In het rapport is daarom een voorgestelde titel $7.13 \mathrm{BW}$ opgenomen inclusief bijbehorende memorie van toelichting. Daarnaast kent het een bijlage ten aanzien van fiscaalrechtelijke effecten. In de voorgestelde regeling zijn aanbevelingen opgenomen voor het oplossen van bekende knelpunten en de opvulling van lacunes onder het huidige recht.

Het ontwerp van de regeling is gebaseerd op dezelfde uitgangspunten als die bij de succesvolle modernisering van het BVrecht. Het rapport geeft een coherente, systematische regeling voor de personenvennootschappen, die voor alle categorieën gebruikers een gebruiksvriendelijke rechtsvorm biedt waarbij zo veel mogelijk tegemoet wordt gekomen aan de behoeften die leven in de praktijk. Een van de doelstellingen hierbij is dat de eventuele implementatie van de voorgestelde regeling tot zo min mogelijk invoeringsfricties leidt voor bestaande personenvennootschappen, terwijl zij gelijktijdig de toepassingsmogelijkheden verruimt voor degenen die daar behoefte aan hebben.

Het ontwerp biedt verschillende noviteiten. Zo wordt de positie van de commanditaire vennoot versoepeld en is een toetredende vennoot slechts aansprakelijk voor verbintenissen van de vennootschap die na zijn toetreden opeisbaar worden. Daarnaast bestaat de mogelijkheid tot afscherming van aansprakelijkheid voor beroepsfouten van medevennoten en is de continuïteit van de vennootschap beter gewaarborgd, omdat de uittreding van een vennoot niet meer leidt tot de ontbinding van de vennootschap.

Een andere in het oog springende verandering is het toekennen van rechtspersoonlijkheid. Een personenvennootschap verkrijgt rechtspersoonlijkheid door inschrijving in het handelsregister. Dit vereenvoudigt de toe- en uittreding van vennoten en biedt mogelijkheden op het gebied van herstructurering, zoals fusie, splitsing en omzetting, waarvoor het voorstel ook een regeling introduceert. De omzetting strekt zich ook uit van en naar andere rechtspersoonsvormen uit Boek 2 BW. 


\section{Maandblad}

Een eerste versie van het rapport is in april 2016 besproken met de Commissie Vennootschapsrecht. Een aangepaste versie van het rapport is vervolgens op 15 juni 2016 bediscussieerd tijdens een congres van het Zuidas Instituut voor Financieel recht en Ondernemingsrecht (ZIFO) en het Van der Heijden Instituut (VHI). ${ }^{5}$ Hierbij kregen verschillende juristen en fiscalisten de kans hun visie te geven op de voorgestelde regeling. Ook organisaties als de Koninklijke Notariële Beroepsorganisatie, de Gecombineerde Commissie Vennootschapsrecht en de Vereniging van Notarieel Ondernemingsrecht Specialisten hebben gereageerd op het rapport.

Bovengenoemde reacties zijn meegenomen bij het opstellen van het definitieve rapport. Dit is op 26 september aangeboden aan minister Van de Steur. Volgens hem sluit het rapport goed aan bij het beleid van het kabinet om het ondernemingsklimaat in Nederland te verbeteren en de (internationale) handelspositie van Nederland te versterken. Hij is voornemens om het rapport te betrekken bij de nota Vernieuwing ondernemingsrecht, die nog dit najaar naar de Tweede Kamer gaat.

De beide versies van het rapport van de Werkgroep Personenvennootschap, zoals besproken bij het congres en aangeboden aan de minister van Veiligheid en Justitie, zijn te vinden op de volgende websites:

- <www.ru.nl/vhi>;

- <www.rechten.vu.nl/nl/nieuws-agenda $>$.

5. P.P.D. Mathey-Bal, Naar een nieuwe regeling voor de personenvennootschap, Ondernemingsrecht 2016/104. 